NBER WORKING PAPER SERIES

\title{
HOW DOES DECLINING UNIONISM AFFECT THE AMERICAN MIDDLE CLASS AND INTERGENERATIONAL MOBILITY?
}

\author{
Richard Freeman \\ Eunice Han \\ David Madland \\ Brendan V. Duke \\ Working Paper 21638 \\ http://www.nber.org/papers/w21638 \\ NATIONAL BUREAU OF ECONOMIC RESEARCH \\ 1050 Massachusetts Avenue \\ Cambridge, MA 02138 \\ October 2015
}

We thank the administrators and seminar participants at the 2015 Federal Reserve System Community Development Research Conference. We thank Larry Summers for his insightful comments at the meeting hosted by Center for American Progress. We thank the NBER and Center for American Progress for providing the necessary resources and assistance. We also thank Alex Rowell and Andrew Schwartz for their input. The views expressed herein are those of the authors and do not necessarily reflect the views of the National Bureau of Economic Research.

NBER working papers are circulated for discussion and comment purposes. They have not been peerreviewed or been subject to the review by the NBER Board of Directors that accompanies official NBER publications.

(C) 2015 by Richard Freeman, Eunice Han, David Madland, and Brendan V. Duke. All rights reserved. Short sections of text, not to exceed two paragraphs, may be quoted without explicit permission provided that full credit, including (C) notice, is given to the source. 
How Does Declining Unionism Affect the American Middle Class and Intergenerational Mobility? Richard Freeman, Eunice Han, David Madland, and Brendan V. Duke

NBER Working Paper No. 21638

October 2015

JEL No. J31,J51,J62

\begin{abstract}
$\underline{\text { ABSTRACT }}$
This paper examines unionism's relationship to the size of the middle class and its relationship to intergenerational mobility. We use the PSID 1985 and 2011 files to examine the change in the share of workers in a middle-income group (defined by persons having incomes within $50 \%$ of the median) and use a shift-share decomposition to explore how the decline of unionism contributes to the shrinking middle class. We also use the files to investigate the correlation between parents' union status and the incomes of their children. Additionally, we use federal income tax data to examine the geographical correlation between union density and intergenerational mobility. We find: 1) union workers are disproportionately in the middle-income group or above, and some reach middle-income status due to the union wage premium; 2) the offspring of union parents have higher incomes than the offspring of otherwise comparable non-union parents, especially when the parents are low-skilled; 3 ) offspring from communities with higher union density have higher average incomes relative to their parents compared to offspring from communities with lower union density. These findings show a strong, though not necessarily causal, link between unions, the middle class, and intergenerational mobility.
\end{abstract}

\author{
Richard Freeman \\ NBER \\ 1050 Massachusetts Avenue \\ Cambridge, MA 02138 \\ freeman@nber.org \\ Eunice Han \\ Wellesley College \\ 106 Central Street \\ Wellesley, Massachusetts 02481 \\ hane@nber.org
}

\author{
David Madland \\ Center for American Progress \\ 1333 H St., NW 10th Floor \\ Washington DC, 20005 \\ dmadland@americanprogress.org \\ Brendan V. Duke \\ Center for American Progress \\ 1400 Irving St NW, Apt. 414 \\ Washington, DC 20010 \\ brendanvduke@gmail.com
}


This paper addresses three ways in which unionism potentially affects workers that the voluminous quantitative literature on "what do unions do" has largely ignored.

The first way relates to the impact of unionism on the size of the middle class. Since unions tend to compress the structure of wages and incomes, and the middle class consists of persons near the middle of the income distribution, we would expect union workers to be primarily in the middle-income group and for a decline in union density to contribute to the shrinking middle class size. This issue has not been widely explored because the shrinking American middle class is a recent phenomenon. Most studies of unions and the distribution of wages and salaries use metrics like the Gini coefficient or the variance of the log of earnings rather than the proportion of workers in the middle of the distribution. Section I shows that union workers are indeed disproportionately middle class or higher, with some attaining middle class incomes as a result of the union wage premium, and that the decline of unionism contributes to the shrinking middle class.

The second previously unexplored way in which unions could affect workers is through the intergenerational transmission of economic status. Section II shows that having a union parent is associated with improved outcomes for children after controlling for parents' education, race, occupation, industry, and other covariates. This could be in part due to the union wage premium raising parental income, in part due to better education and health outcomes associated with having a unionized parent independent of parental income, and in part due to the intergenerational transmission of union status.

The third issue we examine is whether the union density of the area in which a young person grows up is associated with their future economic performance. If parental unionization raises the upward mobility of offspring, children from areas with higher union density ought to do better than children from areas with lower union density. To the extent that unions press for better schooling and social amenities in an area, the union impact should spill over from union to non-union families, producing a residence-based impact beyond the union status of individuals. It could also serve as verification that any potential positive effects of unions on children found in Section II do not reflect a 
redistribution of opportunity from non-union to union children. Section III finds that regardless of the union status of their parents, offspring from communities with higher union density have higher average incomes relative to their parents than offspring from communities with lower union density.

While our findings are not necessarily causal, the relationship between unionism, the middle class, and inequality found in our study and other studies raises the question of whether the US will be able to reduce income equality and rebuild a strong middle class absent a vibrant trade union movement or other comparable institutions for workers.

\section{Unionism and Middle Class Status}

Following Krueger (2012)'s analysis with the March Current Population Survey (CPS), we define middle class as the population aged 25-64 earning an income between 0.5 and 1.5 times the median income level - the portion of the population within 50 percent of the median income. Figure 1 shows that the size of the middle class has fallen by more than 10 percentage points from $56.5 \%$ in 1979 to $45.1 \%$ in 2012 . During the same period, the unionization of American workers declined by 13 percentage points, from $24 \%$ to $11 \%$. ${ }^{1}$

\section{Figure 1: Shrinking Middle-income Group}

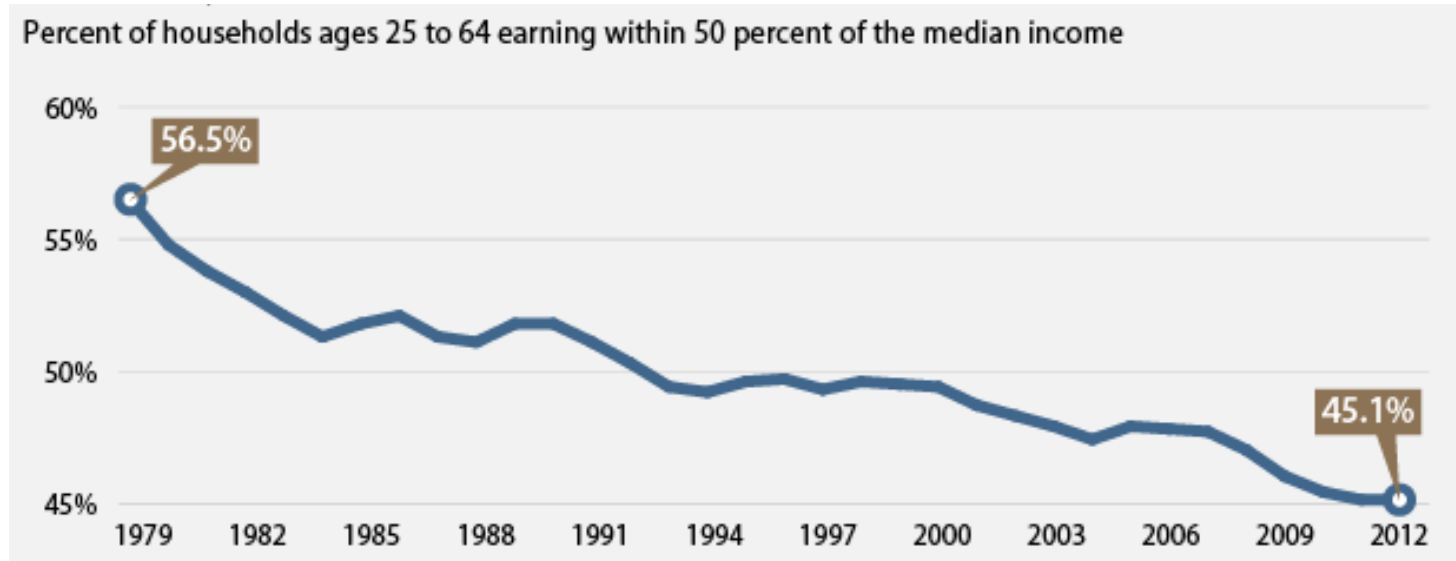

Note: Income measure includes both earned and unearned income. The source is the CPS March data extracts produced by the Center for Economics Policy Research. Available at http://ceprdata.org/cpsuniform-data-extracts/march-cps-supplement/march-cps-data (last accessed November 2014).

\footnotetext{
${ }^{1}$ See http://www.unionstats.com for all wage and salary workers.
} 
To examine the relationship between unionism and middle class status among parents and offspring, we use the Panel Study of Income Dynamics (PSID), which contains information on the incomes and union status of parents and of their adult offspring. It displays a similar decline in the middle-income group to that in the CPS.

\section{Table 1: The Proportion of Unionized and Proportion of Workers by Position in the Income Distribution for Parents and Offspring, by Union Status}

\begin{tabular}{lcccccc} 
& \multicolumn{2}{c}{ All } & \multicolumn{2}{c}{ Unionized } & \multicolumn{2}{c}{ Non-unionized } \\
& Parents & Offspring & Parents & Offspring & Parents & Offspring \\
& 1985 & 2011 & 1985 & 2011 & 1985 & 2011 \\
\hline \hline & & & & & & \\
Proportion Unionized & $19.07 \%$ & $10.90 \%$ & $100 \%$ & $100 \%$ & $0 \%$ & $0 \%$ \\
& & & & & & \\
Income distribution & & & & & & \\
Upper Income Group & $31.61 \%$ & $33.03 \%$ & $31.74 \%$ & $36.67 \%$ & $31.58 \%$ & $32.58 \%$ \\
Middle Income Group & $54.04 \%$ & $46.01 \%$ & $63.50 \%$ & $53.17 \%$ & $51.82 \%$ & $45.13 \%$ \\
Lower Income Group & $14.35 \%$ & $20.96 \%$ & $4.77 \%$ & $10.17 \%$ & $16.60 \%$ & $22.29 \%$
\end{tabular}

Note: Median income is the median of household income for working-age (ages 25-64) heads of household. The 1985 sample represents parents while the 2011 sample represents their children. The middle-income group is heads of household aged 25-64 whose family incomes fall between 0.5 and 1.5 times the median family income. The upper income group is heads of household aged 25-64 whose family incomes are greater than 1.5 times the median family income. The lower income group is heads of household aged 25-64 who earn an income less than 0.5 times the median family income. Data sources are the PSID 1985 and 2011 files.

Table 1 summarizes the pattern of unionization and the proportion of workers in the middle-income group for parents and their children in the PSID data set. We contrast the status of parents in 1985 and the status of their adult offspring in 2011. If heads of household aged 25 to 64 have a family income between $50 \%$ and $150 \%$ of the median income, they are categorized as middle class. We refer to them as the "middle-income group." The table also shows a drop in unionization of 8 percentage points $(19.07 \%$ $10.90 \%$ ) from parents to their offspring and a drop in the proportion of workers in the 
middle-income group by 8 percentage points $(54.04 \%-46.01 \%)$ between parents and their adult children.

Are these changes connected? One way to estimate the contribution of the drop in unionization to the drop in the proportion of persons in the middle-income group is through a shift-share decomposition that divides the change in the middle-income group into two parts: i) the change in union density and ii) the change in the proportion of union workers who were in the middle-income group relative to the proportion of non-union workers in that group. Let $\mathrm{MC}_{\mathrm{U}}$ and $\mathrm{MC}_{\mathrm{N}}$ be the share of union and non-union workers who are in the middle-income group respectively, and let $U$ be the union share of the workforce. Then, if MC (middle class) is the share of the workforce in the middle-income group, we have the following identity:

$$
M C=(1-U) M C_{N}+U M C_{U}=M C_{N}+\left(M C_{U}-M C_{N}\right) U
$$

The statistics in Table 1 show that among parents in 1985 the share of union workers in the middle-income group was 12 percentage points larger than the share of non-union workers in the middle-income group $(63.50 \%-51.82 \%)$. Given the 19 percent of parents who were union in 1985 , unionization contributed 2 percentage points $(0.12 \times 0.19)$ to the overall proportion of workers in the middle-income group among 1985 parents. The effect of unionism on the income distribution of non-union workers through labor market spillovers or through union influence on public policies favorable for workers could produce a larger or smaller impact. ${ }^{2}$

Taking changes of equation (1) over time, the change in the share of the workforce that is middle-income group can be decomposed as following:

\footnotetext{
${ }^{2}$ It will be larger if union wages and benefits spill over to non-union firms who mimic them to avoid union drives or if unions successfully lobby legislatures for laws favorable to all workers (the "threat" effect). It will be smaller if union wages and benefits reduce employment in the union sector, which increases the labor supply and reduces wages in non-union work (the "crowding" effect). Evidence suggests that the threat effect dominates the crowding effect and that unions raise wages for non-union workers (Farber, 2005; Neumark and Wachter, 1995).
} 


$$
\Delta M C=\Delta M C_{N}+\Delta\left(M C_{U}-M C_{N}\right) U+\left(M C_{U}-M C_{N}\right) \Delta U+\Delta\left(M C_{U}-M C_{N}\right) \Delta U
$$

The first term, $\Delta M C_{N}$, measures how the change in the proportion of non-union parents and non-union children in the middle-income group affects the overall change in the size of the middle-income group: this is -7 percentage points $(=45.13 \%-51.82 \%)$. The second term, $\Delta\left(M C_{U}-M C_{N}\right) U$, measures the change in the share of union workers compared to the share of non-union workers in the middle-income group, multiplied by the 19\% parents' unionization rate. The statistics from Table 1 show a 4 percentage point drop ${ }^{3}$ in the difference in the share of union and non-union workers in the middle-income group among parents compared to offspring. To the extent that this reflects weakening unionism over time, it contributes about 0.008 percentage points $(=-0.04 \times 0.19)$ to the fall in the size of the middle-income group.

The third term, $\left(M C_{U}-M C_{N}\right) \Delta U$, is the standard shift component in a shift-share decomposition. It measures the impact of the 8 percentage-point drop in union density between 1985 and 2011 on the proportion of the workforce in the middle-income group, given the difference in the share of union and non-union parents in the middle-income group in 1985 (12 percentage points). It contributes about 1 percentage point $(=-0.08 \mathrm{x}$ $0.12)$ to the fall in the overall size of the middle-income group. The final term, $\Delta\left(M C_{U}-M C_{N}\right) \Delta U$, is the interaction between the change in the share of union and nonunion workers in the middle-income group and the change in union density. It adds about 0.3 percentage points $(=-0.04 \times-0.08)$ to the middle-income group share of the work force.

In sum, the "pure shift effect" of the decline in unionism contributes about 12 percent (= $0.010 / 0.08$ ) to the 8 percentage-point drop in the share of the middle-income group of workers. If we attribute the weakening in unions' ability to boost workers into the middleincome group to the fall in union density, the decline of unionism contributes an additional

\footnotetext{
${ }^{3}$ The difference in the share of union and non-union parents in the middle-income group is 11 percentage points $(=63.50 \%-51.82 \%)$ and the difference in the share of union and non-union offspring in the middleincome group is 7 percentage points $(=53.17 \%-45.13 \%)$. This results in a $4(=7-11)$ percentage-point drop from parents to offspring in terms of the gap between union and non-union proportion in the middle class.
} 
0.7 percentage points to the drop, thus accounting for almost 20 percent $(=(0.007+$ 0.010)/0.08) to the decline of the middle-income group. If we assume the wage distribution of union and non-union workers was stable between 1985 and 2011, and union density remained at its 1985 level, the size of the middle-income group in 2011 would have been higher by 1.4 percentage points (17\% of 8 percentage points).

As noted above, the reason union workers are disproportionately in the middle-income group is that collective bargaining tends to compress the distribution of wages for covered workers so that union workers have a narrower distribution than non-union workers (Western and Rosenfeld, 2011; Card, Lemieux and Riddell, 2004; Pontusson, Rueda, and Way, 2002; DiNardo, Fortin, and Lemieux, 1996; Freeman, 1980, 1993; Card, 1992). Figure 2 shows this phenomenon separately for parents in 1985 and for their offspring in 2011. For both parents and offspring, the income distribution of union workers is more concentrated towards the center compared to that of non-union workers. The income distribution of offspring, however, is more dispersed than the income distribution of their parents, which reflects the higher income inequality in 2011 than in 1985.

\section{Figure 2: Income Distribution for Union Workers and Non-union Workers}

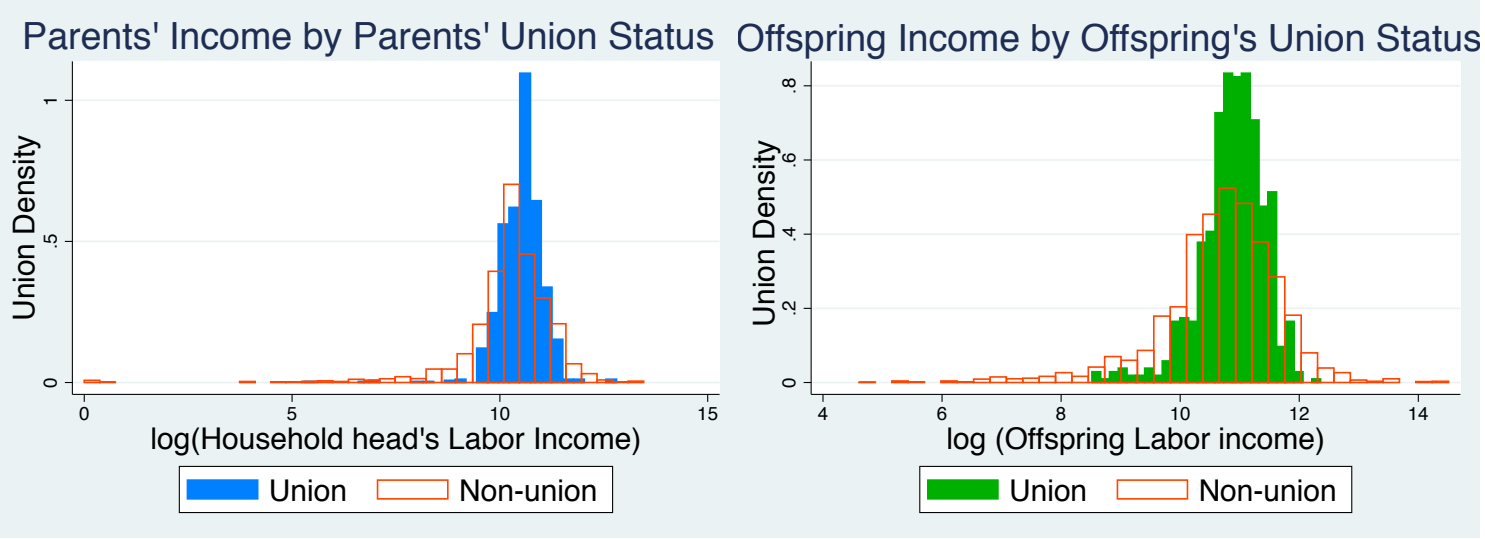

Note: The income distribution is constructed from the labor income of working-age (ages 25-64) samples. Data sources are the PSID 1985 and 2011 files.

From this perspective, the statistics from Table 1 on the fraction of people making less than $50 \%$ of median income deserves particular attention. The fraction of people who 
belong to this lower income group increased from 14\% among parents in 1985 to $21 \%$ among offspring in 2011. The decline in unionization might have contributed to the fraction of young workers who did not make it to the middle-income group. Modifying equation (2) to assess the effect of the fall in unionism on the higher share of offspring than of parents in the lower income group, we estimate that the decline in the union density between parents and offspring contributes about 1 percentage point ${ }^{4}$ to the 7 percentage-point greater share of offspring than their parents in the lower income group, or 14 percent.

In sum, however we organize the data, the decline of unionism appears to have contributed to the shrinkage of the middle-income group of the workforce and the increasing proportion of the lower income group, with a noticeable but not huge magnitude commensurate with unions' declining role in the US labor market. To the extent that the decline of unions impairs the wages of non-union workers, as Rosenfeld and Western (2011) argue, ours is a conservative estimate of the impact of falling unionism on the middle class.

\section{Unionism and Intergenerational Transmission of Economic Status}

The PSID provides details on the characteristics of families, including the labor income and union status of the household head and of the head's wife ${ }^{5}$, and of their adult offspring 20-30 years later. To obtain a sample of parents and their adult offspring, we matched the 1985 and 2011 PSID files by individual and created a new file limited to individuals who were children or stepchildren of the head of a household in 1985 and were heads of household or the wives of household heads in 2011. We also restrict our offspring sample to be younger than 38 years old in 2011 (younger than 12 years old in 1985) so that they are young enough to be influenced by parents' economic status.

\footnotetext{
${ }^{4}$ We obtain the 0.01 percentage-point estimate by multiplying the different shares of union and non-union parents in the low-income group $(16.6 \%-4.77 \%)$ by the 8 percentage-point difference in union density between 1985 and 2011.

${ }^{5}$ The PSID defines head of household as someone over age 16 with the most financial responsibility, but if that person is female and married to a man, then he is the head and she is the wife. Therefore, a woman is only the head of household if the household has no adult male who is not incapacitated. The wife also does not necessarily need to be legally married to the household head to be considered a wife in the PSID.
} 
We created a new set of 2011 "offspring" variables to characterize this group characteristics of the household heads if the individual was the head of household and characteristics of the wives if the individual was the married or unmarried partner of the male household head. These offspring variables are designed to focus on the relationships between parents and their children rather than between parents and the spouses of their children. ${ }^{6}$ Appendix B gives the summary statistics of the main PSID variables in our analysis.

Table 2: Average Labor Income of Offspring by Parents' Union \& Education Status

\begin{tabular}{|c|c|c|c|c|}
\hline & & Parents & $\begin{array}{l}\text { Parents without } \\
\text { College Degree }\end{array}$ & $\begin{array}{l}\text { Parents with } \\
\text { College Degree }\end{array}$ \\
\hline \multirow{3}{*}{$\begin{array}{l}\text { Offspring of } \\
\text { Union Parents }\end{array}$} & $\begin{array}{l}\text { Labor Income, } \\
\text { (Full-time) }\end{array}$ & $\$ 48,000$ & $\$ 45,600$ & $\$ 53,300$ \\
\hline & $\begin{array}{l}\text { Highest Grades } \\
\text { Completed }\end{array}$ & 14.74 & 14.39 & 15.52 \\
\hline & $\begin{array}{c}\text { Health } \\
(1-5,5=\text { Excellent })\end{array}$ & 3.85 & 3.75 & 4.07 \\
\hline \multirow{3}{*}{$\begin{array}{l}\text { Offspring of } \\
\text { Non-union } \\
\text { Parents }\end{array}$} & $\begin{array}{l}\text { Labor Income } \\
\text { (Full-time) }\end{array}$ & $\$ 45,700$ & $\$ 39,300$ & $\$ 53,800$ \\
\hline & $\begin{array}{l}\text { Highest Grades } \\
\text { Completed }\end{array}$ & 14.67 & 13.78 & 15.78 \\
\hline & $\begin{array}{c}\text { Health } \\
(1-5,5=\text { Excellent })\end{array}$ & 3.88 & 3.78 & 4.02 \\
\hline
\end{tabular}

Note: Difference between union and non-union college graduate parents is not statistically significant Calculations are for 26- to 37-year-olds who work full time and who had at least one parent who worked full time in 1985. Data sources are the PSID 1985 and 2011 files. Offspring are in the "union parents" group if they have at least one union parent, and in the "parents with college degree" group if they have at least one college-grad parent.

To provide a first look at the relation between parents' union status and their children's income, we compare the labor incomes of full-time offspring by the union status of their parents. Table 2 presents the simple tabulation of unconditional average incomes of children in the sample differentiated by their parents' union status and educational status. Overall, offspring of union parents earn higher incomes than offspring of non-union parents. This difference is more conspicuous for offspring of parents with lower education

\footnotetext{
${ }^{6}$ Because we limit our analysis to heads of household and wives, our data exclude children who were not heads of household or wives, consisting primarily of those living with their parents in 2011.
} 
status. Among children whose parents did not graduate college, the average income of children with a union parent exceeds the average income of children with non-union parents by $\$ 6,300$, or 16 percent, a difference that is significant at the 1 percent level. The educational attainment is also higher for offspring of union parents. The difference in the average health status between offspring of union and non-union parents is not statistically different from zero. For children who have at least one parent graduated college, parental union status had little effect on offspring income. This suggests that unions increase opportunity for children who need it most.

The evidence that the offspring of union parents do better than the offspring of non-union parents raises the question of whether these differences reflect the impact of unionism on offspring outcomes or are the result of observed or unobserved attributes of union parents that give their children an advantage independent of parental union status. Our methods do not allow us to determine the effect of unobserved attributes, but do allow us to isolate the union effect from observed attributes in the PSID survey.

To see whether the Table 2 differences remain in the presence of other measures of parental attributes, we regress the log of offspring income on the log of their parental income and other parental characteristics using the following form:

$$
\log Y_{j k}=\beta_{0}+\beta_{1} U_{k}^{p}+\beta_{2} \log Y_{k}^{p}+\sum_{k} X_{k}^{p}+\varepsilon_{j k}
$$

where $\mathrm{j}$ indexes offspring and $\mathrm{k}$ indexes their parents. $\mathrm{Y}$ is offspring's labor income $\mathrm{e}^{7} ; \mathrm{U}^{\mathrm{P}}$ is their parents' union status, where 1 indicates unionized and 0 non-union ${ }^{8} ; \mathrm{Y}^{\mathrm{P}}$ is parents' family income and $X^{\mathrm{P}}$ represents other parental attributes, such as parents' age, race, and ethnicity, their full-time status, education, marital status, industry, and occupations, and the urban status of the household. If $\mathrm{U}^{\mathrm{P}}$ is significantly positive, on average the offspring of union parents earn higher income than the offspring of non-union parents.

\footnotetext{
${ }^{7}$ To measure the direct effect of parents' unionism on offspring income, we focus on offspring's labor income rather than the combined family income of married couples. The use of labor income drops offspring with self-employed status or those out of labor force.

${ }^{8}$ For parents' union status, we look at fathers and mothers separately.
} 
Table 3: Estimated Relation between Parents' Family Income and Union Status on Log (Adult Offspring Income)

VARIABLES

(1)

(2)

(3)

(4)

(5)

(6)

\begin{tabular}{lcccccc}
\hline \hline & & & & & & \\
Log(family income) & $0.326^{* * *}$ & $0.239^{* * *}$ & & $0.224^{* * *}$ & & $0.237^{* * *}$ \\
& $(0.074)$ & $(0.068)$ & & $(0.070)$ & & $(0.070)$ \\
Union Father & & & $0.187^{* * *}$ & $0.0164^{* *}$ & $0.185^{* * *}$ & $0.160^{* *}$ \\
& & & $(0.062)$ & $(0.064)$ & $(0.060)$ & $(0.061)$ \\
Union Mother & & & 0.073 & 0.023 & 0.060 & 0.005 \\
& & & $(0.087)$ & $(0.085)$ & $(0.085)$ & $(0.083)$ \\
Union Offspring & & & & & $0.186^{* * *}$ & $0.206 * * *$ \\
& & & & & $(0.059)$ & $(0.058)$ \\
Other covariates & NO & YES & YES & YES & YES & YES \\
State clustered SE & YES & YES & YES & YES & YES & YES \\
Observations & 1,068 & 1,068 & 1,068 & 1,068 & 1,068 & 1,068 \\
R-squared & 0.066 & 0.188 & 0.179 & 0.193 & 0.186 & 0.201
\end{tabular}

Note: Clustered standard errors in parentheses. $* * * \mathrm{p}<0.01, * * \mathrm{p}<0.05, * \mathrm{p}<0.1$. Child labor income is the labor income of individuals who were under age 12 in 1985, had at least one parent work full time in 1985, and worked full time in 2011. Family income is the household income of the parents. Other covariates include parental age, education, full-time status, race, industry, occupation, marital status, and the household's urban status.

Table 3 gives the results of the regressions of log (offspring income) on parents' attributes including parents' family income. ${ }^{9}$ The coefficient on log (family income) in column 1 is the intergenerational income elasticity (IGE) that measures the association between parental income and offspring income. The estimated coefficient of 0.33 indicates that if parental income increases by $10 \%$, offspring's labor income increases by $3.3 \%$ for all persons in the sample. ${ }^{10}$ The addition of covariates for parental attributes reduces the coefficient to 0.24 in column 2.

\footnotetext{
${ }^{9}$ The full results for all of our regression analyses are available upon request.

${ }^{10}$ Although we use labor income rather than family income of offspring to measure the IGE, this estimate is consistent with literature (Chetty et al., 2014; Lee and Solon, 2006). Mazumder (2005) states that the
} 
Column 3 of Table 3 examines the effect of having union parents on offspring income absent family income but with inclusion of other parental covariates. The binary variable for union status of the father is significant and robust with a magnitude of 0.19 , which implies that the adult offspring of unionized fathers earn 19\% higher income than the adult offspring of non-unionized fathers. The binary variable for the union status of the mother is positive but insignificant. ${ }^{11}$

Adding parental family income in column 4 reduces the coefficient on the union status of the father to 0.16 , which is still statistically significant. This suggests that the effect of the father's unionism goes beyond their higher income due to the union wage premium.

Finally, in columns 5 and 6, we add a dummy variable indicating whether the offspring is unionized. The estimated coefficients on father's union status and parental income do not change much after we include offspring's union status, even though the estimated coefficient on offspring union status shows that offspring earn a substantial union premium. Compared to offspring whose fathers and themselves have no connection to unionism, offspring whose parents are unionized and themselves are also unionized earn about $36 \%(=16 \%+20 \%)$ higher labor income. ${ }^{12}$

It is worth noting, however, that these union premia for offspring are not directly comparable to other union premia found in the literature since we do not control for the child's attributes such as education, experience, industry, occupation, and other typical controls. We only use the child's union status as on the right side of the regression model to capture the "full effect" of parental union status on children's income, as other controls of offspring could also reflect the indirect effect of unionism through children's education, health, or occupation choice. ${ }^{13}$

estimated IGE could be subject to the attenuation bias if the data focus on short-term periods, because there could be a long-lasting transitory shock to income.

${ }^{11}$ We also use a binary variable indicating if at least one of the parents is a union member ( 1 if the father or mother is union and 0 of both of them are non-union), and the coefficient is 0.15 and statistically significant at $1 \%$ of the significance level.

${ }^{12}$ We also analyze the effect of parents' unionism controlling for separate labor incomes of household heads and their wives rather than controlling for parent's family income, and we obtain similar results.

${ }^{13}$ If we control for children's attributes and parents' union status, the union premium of offspring is $15 \%$. 
Table 4: Estimated Relation between Parents' Family Income and Union Status

on Log (Adult Sons' Income) and Log (Adult Daughters' Income)

Sons $\quad$ Daughters

VARIABLES

(1)

(2)

(3)

(4)

(5)

(6)

(7)

(8)

\begin{tabular}{|c|c|c|c|c|c|c|c|c|}
\hline \multirow[t]{2}{*}{ Log(family income) } & & 0.201 & & $0.212 *$ & & $0.265^{* *}$ & & $0.283 * * *$ \\
\hline & & $(0.129)$ & & $(0.126)$ & & $(0.106)$ & & $(0.104)$ \\
\hline \multirow[t]{2}{*}{ Union Father } & 0.142 & 0.125 & 0.133 & 0.115 & $0.219 * * *$ & $0.181 * *$ & $0.220 * * *$ & $0.181^{* *}$ \\
\hline & $(0.087)$ & $(0.087)$ & $(0.083)$ & $(0.083)$ & $(0.070)$ & $(0.072)$ & $(0.070)$ & $(0.071)$ \\
\hline \multirow[t]{2}{*}{ Union Mother } & -0.017 & -0.054 & -0.014 & -0.053 & 0.240 & 0.162 & 0.219 & 0.130 \\
\hline & $(0.137)$ & $(0.137)$ & $(0.133)$ & $(0.132)$ & $(0.145)$ & $(0.137)$ & $(0.146)$ & $(0.141)$ \\
\hline \multirow[t]{2}{*}{ Union Offspring } & & & $0.247 * *$ & $0.260 * *$ & & & 0.133 & 0.173 \\
\hline & & & $(0.073)$ & $(0.074)$ & & & $(0.112)$ & $(0.115)$ \\
\hline Other covariates & YES & YES & YES & YES & YES & YES & YES & YES \\
\hline State clustered SE & YES & YES & YES & YES & YES & YES & YES & YES \\
\hline Observations & 566 & 566 & 566 & 566 & 502 & 502 & 502 & 502 \\
\hline R-squared & 0.231 & 0.241 & 0.242 & 0.253 & 0.228 & 0.246 & 0.231 & 0.252 \\
\hline
\end{tabular}


Disaggregating the analysis by gender of offspring, we obtain the results in Table 4 . The effects of log family income on log of offspring income are similar for sons and daughters, but the result is greater and more significant for daughters than for sons (the effect for sons is not statistically significant at the 90 percent level but this likely reflects the fact that we have cut the sample size by approximately half from Table 3). Fathers' union status has a greater impact on daughters' income than on sons', but the sign of the union status is consistently positive across model specifications for sons.

\title{
Table 5: The Effect of Parents' Unionism on Education Attainment and Health Status of Offspring
}

\author{
Highest Grade Completed $\quad$ Health $(1-5,5=$ Excellent $)$
}

VARIABLES

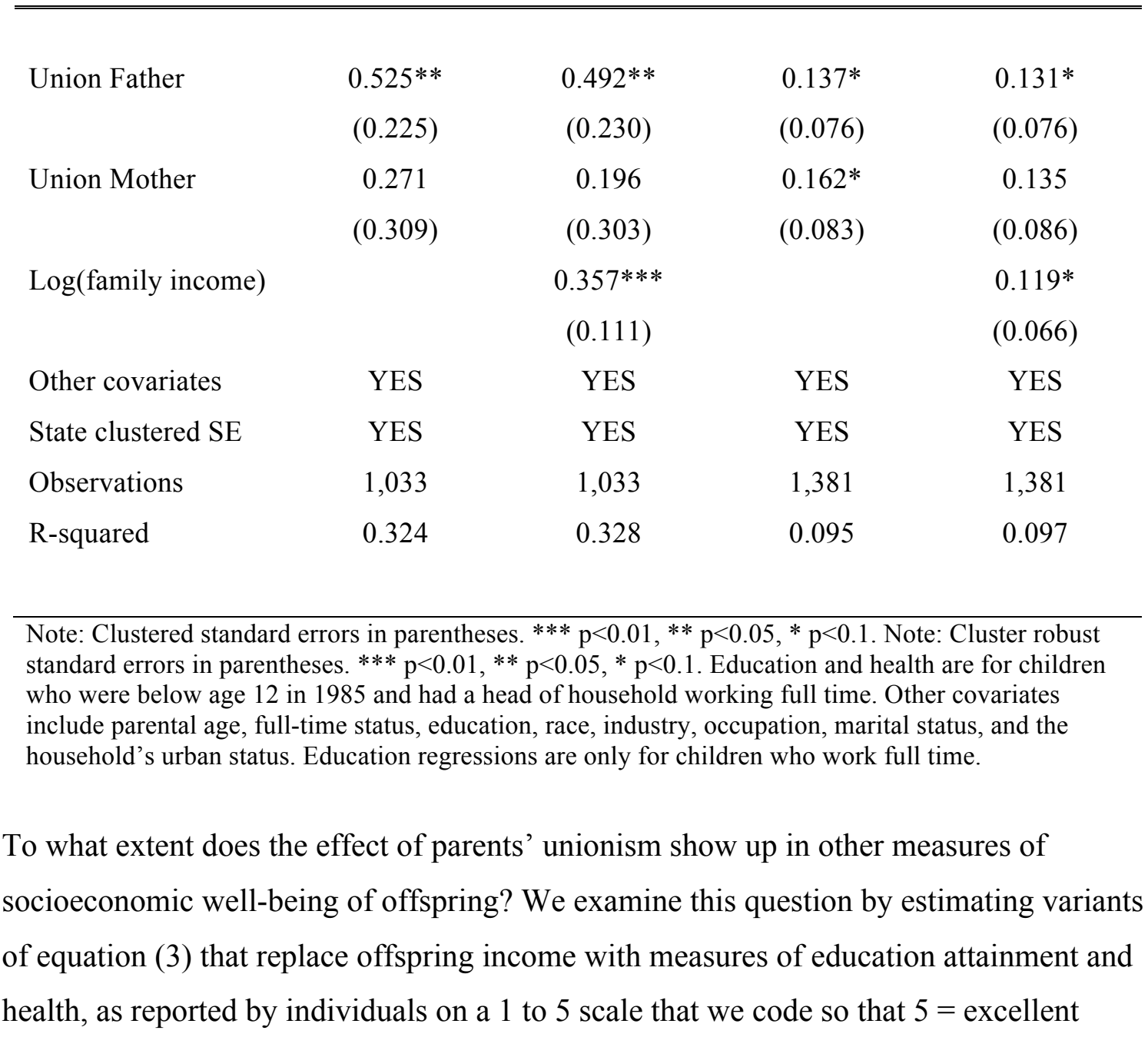


health and $1=$ poor health status. In Table 5 , the results for the education measure show that for offspring having a union father, the highest grade completed even with the same family income (columns 1 and 2) substantially increases. Columns 3 and 4 of Table 5 give the results for the health measure of offspring. The health status of offspring is positively associated with both father's and mother's union status. The results hold with the addition of family income. This may reflect health care and childcare benefits that unions provide to their members. Higher education attainment and better health status of offspring of union parents will also contribute to higher lifetime earnings of offspring.

Given the many pathways by which educated and skilled workers pass on economic advantages to their children, it is important to determine whether the union parents' effect on offspring income is stronger among more educated and skilled workers or among less educated and skilled workers. In the former case, the union effect would reduce relative mobility associated with education and skill while in the latter case the union effect would increase relative mobility.

We examine this issue by dividing our sample into fathers with no college education and fathers with at least some college education and between fathers in blue-collar occupations compared to fathers in white-collar occupations. We use this educational cutoff because it maximizes sample size in the high- and low-skill groups. We then estimate equations (3) and (4) for these groups. The results in Table 6 show that the union effect in raising the income of offspring is concentrated among the children of fathers with less education and blue-collar jobs. While one potential explanation is the large union wage premium for low-skilled workers (Hirsch and Schumacher, 1998), the inclusion of the father's labor income variable, which should reflect the wage premium, still leaves a sizable independent union effect.

\section{Living in a Higher Union Density Community}

We examine next the link between the rate of unionization in the geographic community in which young persons were raised and their future income, conditional on their parents' 
Table 6: Estimated Effect of Fathers' Unionism and Income on Log (Offspring Income),

\section{by Parents' Education or Occupational Group}

\begin{tabular}{|c|c|c|c|c|c|c|c|c|}
\hline \multirow[b]{2}{*}{ VARIABLES } & \multicolumn{2}{|c|}{ No College } & \multicolumn{2}{|c|}{$\begin{array}{c}\text { At Least } \\
\text { Some College }\end{array}$} & \multicolumn{2}{|c|}{ Blue collar } & \multicolumn{2}{|c|}{ White collar } \\
\hline & (1) & (2) & (3) & (4) & (5) & (6) & (7) & $(8)$ \\
\hline \multirow[t]{2}{*}{ Union Father } & $0.275^{* * *}$ & $0.195 * *$ & 0.107 & 0.104 & $0.213 * * *$ & $0.146^{* *}$ & 0.067 & 0.067 \\
\hline & $(0.083)$ & $(0.088)$ & $(0.086)$ & $(0.085)$ & $(0.075)$ & $(0.069)$ & $(0.100)$ & $(0.100)$ \\
\hline \multirow[t]{2}{*}{ Log (Father labor income) } & & $0.284 * * *$ & & 0.059 & & $0.293 * * *$ & & 0.036 \\
\hline & & $(0.066)$ & & $(0.097)$ & & $(0.069)$ & & $(0.122)$ \\
\hline Other covariates & Yes & Yes & Yes & Yes & Yes & Yes & Yes & Yes \\
\hline State clustered SE & Yes & Yes & Yes & Yes & Yes & Yes & Yes & Yes \\
\hline Observations & 435 & 435 & 479 & 478 & 498 & 497 & 416 & 416 \\
\hline R-squared & 0.234 & 0.263 & 0.059 & 0.06 & 0.194 & 0.23 & 0.047 & 0.047 \\
\hline
\end{tabular}


income and the average income in their community. To do this we first obtain the average 2011-2012 family incomes of a 1980-1982 birth cohort linked to the average 1996-2000 family incomes of their parents by county and commuting zone from "Intergenerational Mobility Statistics and Selected Covariates by County" data provided by Chetty et al. $(2014)^{14}$. We combine this data with union density data from Hirsch and McPherson's Unionstats CPS-based estimates for metropolitan statistical areas. Matching the two data sets involves technical complications that we describe in Appendix C; summary statistics for this matched data are given in Appendix D. ${ }^{15}$

Aggregation of the parent-offspring relation in section II should by itself produce a relationship between unionization of an area and future incomes of children raised in the area relative to their parents' income. If children from unionized families earn higher incomes than children from otherwise comparable non-union families, aggregating the parental income during their formative years and the future incomes of children brought up in the area should yield higher incomes for children relative to parents in areas with higher union density. But the rate of unionization of an area may also affect the future incomes of all children in the area through potential union impacts on area resources (spillover effects of unionism). Unions generally advocate policies that benefit workers, such as raising minimum wages, increasing education spending, and improving public services, so that the effect of unionism may show up in higher incomes for all children from the area regardless of the union status of their parents. ${ }^{16}$

\footnotetext{
${ }^{14}$ The data by commuting zone and county is publicly available at www.Equality-of-Opportunity.org.

${ }^{15}$ Most covariates come from the publicly available folder of Chetty et al. on www.Equality-OfOpporunity.org: population, percent of children with a single mother, commute time, high school dropout rates, college graduation rates, local tax and spending, the Gini coefficient, social capital, a state's Earned Income Tax Credit coverage, and the progressivity of the state's tax code. Single mother rates, dropout rates, and commute times were four of the "five factors" Chetty et al. found significant in their analysis. We do not include the Gini coefficient of just the bottom $99 \%$, because it is based on their non-public tax data and is not provided at the county level. We add other covariates: first, industry, since some industries are more unionized than others, from data on industries in the Chetty et al. raw data folder from the 2000 Census: "Sex by Industry for the Employed Civilian Population 16 Years and Over." We place the industries into five categories. Second, we create multiple race variables. Using race data from the 2000 Census in the National Historical Geographic Information System (NHGIS) in the public data folder of Chetty et al., we created variables for the percentage of the MSA that is non-Hispanic black, non-Hispanic Asian, non-Hispanic "other," and Hispanic. Third, we add US Census data from 2000 on the child poverty rate, average number of children per family, and median value of owner-occupied housing units.

${ }^{16}$ Cox and Oaxaca (1982) find that states with higher union density have higher minimum wages. Gilens (2014) shows that unions are advocates for policies supported by the middle-income group.
} 
As our area data contain no information on the individuals within the area, we cannot distinguish the two possible routes of impact. Our analysis is limited to the overall relationship between the union density of a community and the future income of children who grow up in the community.

\section{Figure 3: The Correlation between Union Density and Mobility of Offspring}

\section{Within Commuting Zones}

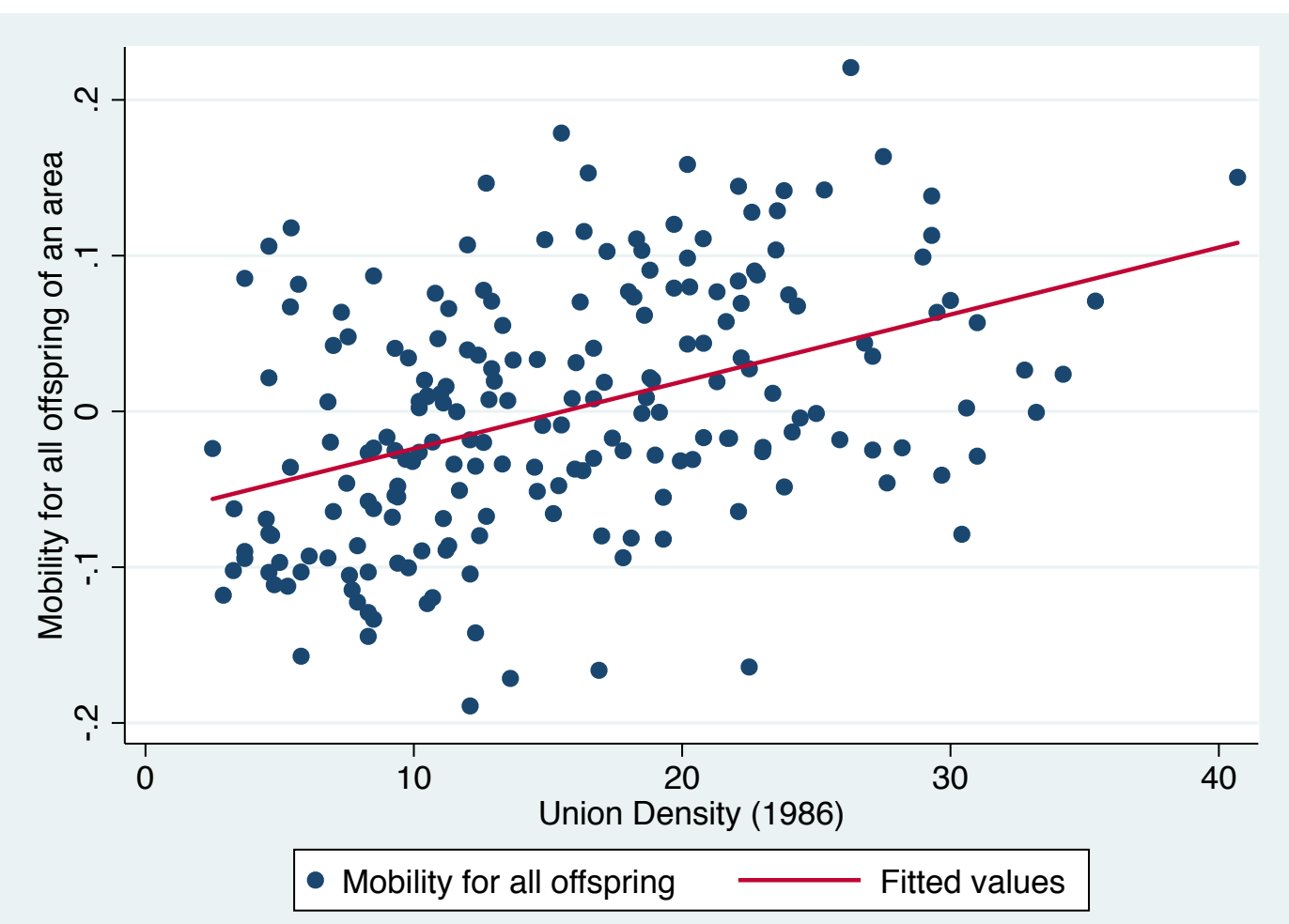

Note: Mobility for all offspring of an area is the residual from a regression of the log mean child income in an area on the log mean parent income of that area. The union density by commuting zone is from 1986 and the offspring income is from 2011-2012 for the 1980-1982 birth cohort.

Figure 3 shows a scatter plot that depicts the correlation between union density of an area and the residual earnings from a regression of the log mean offspring income on the log mean parent income of that area. Since the residual captures the earnings that are not associated with parental income, it can measure the mobility of all offspring in an area. The figure presents the positive association between the unionization of a community and the future income of children brought up in that community, controlling for their parents' 
incomes. The 2011-2012 income (controlling for parents' income) for the 1980-1982 birth cohort is higher if they grew up in the commuting zones with higher union density.

To estimate the magnitude of the effect of union density on the 2011-2012 income of persons who had resided in that zone, we use the following model:

$$
\log \bar{Y}_{i}^{o}=\beta_{0}+\beta_{1} U_{i}^{p}+\beta_{2} \log \bar{Y}_{i}^{p}+\sum d_{i} X_{i}+\varepsilon_{i}
$$

where $\mathrm{i}$ indexes commuting zone (CZ), o indexes offspring, and $\mathrm{p}$ indexes their parents. $\bar{Y}_{i}^{p}$ measures the average income of parents in the $\mathrm{i}^{\text {th }} \mathrm{CZ}$ over 1996-2000, and $\bar{Y}_{i}^{o}$ measures the average income of offspring in the same $\mathrm{CZ}$. The union density figure is for 1986, which is when the young persons would have been 4-6 years old. Because relative union density by area is a stable statistic, the results should be similar for union density over other time periods. To reduce the potential that the effect of unionism will be confounded with that of other area variables, the $X$ vector in the regression controls for a large set of covariates, including many that could be channels for unionism to increase mobility such as, social capital, tax progressivity, the coverage of a state EITC, and lower child poverty, as listed in the note to Table 7 .

Column 1 of Table 7 gives the estimated coefficient on log of the mean parental income in $\mathrm{CZ}$ on the $\log$ of the mean of their offspring income with inclusion of various covariates. The coefficient shows that a 10 percent increase in a CZ's average parents' income increases the average income of offspring in that $C Z$ by 6.2 percent ${ }^{17}-$ a larger IGE than we found in the regressions for individuals, possibly due to lower measurement error for area incomes or to neighborhood spillovers. When we add union density to the Column 2 regression, we find that an area's union density is indeed positively related to its intergenerational mobility. Column 3 puts the estimated union density effect to a stringent test by including dummy variables for each state. The coefficient on union

\footnotetext{
${ }^{17}$ The coefficient on the parents' income is similar to an IGE — a typical measure of immobility—but has a different interpretation since an IGE based on individual income and this elasticity is based on the mean income of individuals within an area. Hence, there is a single elasticity for each CZ.
} 
density falls but still remains substantial - a 10 percent increase in union density is associated with a two percent increase in child income. The robustness of the results strongly suggests that the positive relationship between parents' unionism and offspring income is more than a correlation. ${ }^{18}$

\section{Table 7: Estimated Effect of Area Unionism on Log (Mean Offspring Income)}

\begin{tabular}{|c|c|c|c|}
\hline VARIABLES & (1) & (2) & (3) \\
\hline \multirow[t]{2}{*}{ Log(mean parents' income) } & $0.617 * * *$ & $0.547 * * *$ & $0.582 * * *$ \\
\hline & $(0.063)$ & $(0.079)$ & $(0.053)$ \\
\hline \multirow[t]{2}{*}{ Union density, 1986} & & $0.309 * * *$ & $0.198 * * *$ \\
\hline & & $(0.127)$ & $(0.072)$ \\
\hline Other covariates & YES & YES & YES \\
\hline State dummies & & & YES \\
\hline State clustered SE & YES & YES & YES \\
\hline Observations & 203 & 161 & 161 \\
\hline R-squared & 0.617 & 0.889 & 0.970 \\
\hline \multicolumn{4}{|c|}{$\begin{array}{l}\text { Note: Clustered standard errors in parentheses. } * * * \mathrm{p}<0.01, * * \mathrm{p}<0.05, * \mathrm{p}<0.1 \text {. } \\
\text { Covariates include population size, race, percent of children with a single mother, } \\
\text { commute time, occupational sector, high school dropout rates, child poverty rate, } \\
\text { average number of children per family, median value of owner-occupied housing units, } \\
\text { per capita local tax and spending, the Gini coefficient, social capital, whether the state } \\
\text { has an Earned Income Tax Credit, and the progressivity of the state's tax code. }\end{array}$} \\
\hline
\end{tabular}

In sum, the area data, which was derived from a different data source than the PSID, tell a similar story about the positive association of unionism to the income progress of young persons. The data also show that unionism is highly correlated with the well-being of all children in an area, not just children of union parents. While the data do not allow us to decompose the area effects into those due to more young people growing up in union

\footnotetext{
${ }^{18}$ As a robustness check, we also perform an analysis of the effects of areas' union density on mobility within that area using the "absolute upward mobility (AM)" measure used in Chetty et al. We find that the expected income ranking of children whose parents are at the $25^{\text {th }}$ percentile of the national income distribution is higher if the children grew up in a community with higher union density (see Appendix $\mathrm{E}$ for a detailed description and the result of our analysis). Although the AM focuses on disadvantaged children, the result is consistent with our findings in Table 7.
} 
homes or larger spillover effects, the similarity of the estimated union effects provides some assurance that the results are not the artifact of a particular kind of data or modeling exercise.

\section{Discussion}

The evidence in this paper shows that parents' unionism has a significant relationship with their offspring's well-being. The adult offspring of unionized parents earn higher labor income compared to the offspring of non-unionized parents. The offspring of unionized parents also attain higher levels of education and better health status. The intergenerational union premium is stronger for less educated/skilled parents than for more educated/skilled parents. The evidence also suggests that there may be spillover effects of unionism. We find that relative to their parents, the children of an area with high union density are better off.

Our findings suggest a strong relationship exists between unions, mobility, and the middle class. Proving causality, however, is difficult without experimental or quasiexperimental data, which have become the gold standard in modern empirical economics. But we hope that these findings will trigger further research into whether a causal relationship between unions and intergenerational mobility exists.

If there is a causal component to the strong correlations we have found, the natural implication is that the US will find it harder to address the problem of the diminishing middle-income group than if trade unions were as strong and viable as they were 30, 40, or 50 years ago. A strong union movement is not simply sufficient for high levels of intergenerational mobility and middle-class membership, but it could be necessary. If that is the case, it will be difficult to meaningfully increase intergenerational mobility and rebuild the middle class without also rebuilding unions or some comparable workerbased organizations. 


\section{Reference}

Card, David. 1992. "The Effect of Unions on the Distribution of Wages: Redistribution or Relabelling?” National Bureau of Economic Research Working Paper 4195.

Card, David, Thomas Lemieux and W. Craig Riddell. 2004. "Unions and Wage Inequality." Journal of Labor Research 25.

Cox, James M. and Ronald L. Oaxaca. 1982. "The Political Economy of Minimum Wage Legislation," Economic Inquiry, 20 (4): 533-555.

Current Population Survey March data extracts, Center for Economics Policy Research. Available at http://ceprdata.org/cps-uniform-data-extracts/march-cps-supplement/marchcps-data (last accessed November 2014).

Chetty, Raj, Nathaniel Hendren, Patrick Kline, and Emmanuel Saez. 2014. "Where is the Land of Opportunity: The Geography of Intergenerational Mobility in the United States," Quarterly Journal of Economics, 129 (4): 1553-1623.

Corak, Miles. 2013. "Income Inequality, Equality of Opportunity, and Intergenerational Mobility," Journal of Economic Perspectives, 27(3): 79-102.

DiNardo, John, Nicole M. Fortin, and Thomas Lemieux. 1996. "Labor Market Institutions and the Distribution of Wages, 1973-1992: A Semiparametric Approach," Econometrica, 64 (6): 1001-1044.

Farber, Henry S. 2005. "Nonunion Wage Rates and the Threat of Unionization," Industrial Relations Review, 28 (3): 335-352.

Freeman, Richard B. 1992. "How Much Has De-Unionisation Contributed to the Rise in Male Earnings Inequality?”, NBER WP \#3826, 8/91; Chapter 4 in Sheldon Danziger and Peter Gottschalk (eds) Uneven Tides (NY: Sage Press) pp 133-163.

Freeman, Richard B. 1991. "Labor Market Tightness and the Mismatch Between Demand and Supply of Less-Educated Young Men In the United States in the 1980s," Chapter 8 in editor, Fiorella Padoa-Schioppa, ed. Mismatch and Labour Mobility. NY: Cambridge University Press, pp: 360-85.

Gilens, Martin. 2014. Affluence and Influence: Economic Inequality and Political Power in America. Princeton, NJ: Princeton University Press

Hirsch, Barry T. and David A. Macpherson. 2003. "Union Membership and Coverage Database from the Current Population Survey: Note," Industrial and Labor Relations Review, 56 (2): 349-54. Updated data available at http://www.UnionStats.com 
Hirsch, Barry T. and Edward J. Schumacher. 1998. "Unions, Wages, and Skills," Journal of Human Resources, 33 (1) 201-19.

Krueger, Alan B. 2012. "The Rise and Consequences of Inequality in the United States." Speech at the Center for American Progress, available at http://www.whitehouse.gov/sites/default/files/krueger_cap_speech_final_remarks.pdf

Lee, Chul-In and Gary Solon. 2006. "Trends in Intergenerational Mobility?", National Bureau of Economic Research Working Paper \#12007.

Mazumder, Bhashkar. 2005. "Fortunate Sons: New Estimates of Intergenerational Mobility in the United States Using Social Security Earnings Data." The Review of Economics and Statistics, 87 (2): 235-255.

Neumark, David and Michael L. Wachter. 1995. "Union Effects on Nonunion Wages: Evidence from Panel Data on Industries and Cities," Faculty Scholarship. Paper 1369.

Pontusson, Jonas, David Rueda, and Christopher R. Way. 2002. "Comparative Political Economy of Wage Distribution: The Role of Partisanship and Labor Market Institutions," British Journal of Political Science, 32 (2): 281-308

Western, Bruce and Jake Rosenfeld. 2011. "Unions, Norms, and the Rise in U.S. Wage Inequality," The American Sociological Review, 76 (4): 513-537. 


\section{Appendix A: Summary Statistics from the PSID 1985 and 2011 Files}

\begin{tabular}{|c|c|c|c|c|c|}
\hline VARIABLES & $\mathrm{N}$ & Mean & SD & Min & Max \\
\hline Family Income (Parent) & 1,084 & $\$ 36,120$ & $\$ 19,505$ & $\$ 2,952$ & $\$ 126,800$ \\
\hline Wife Labor Income (Parent) & 971 & $\$ 6,549$ & $\$ 8,043$ & 0 & $\$ 60,000$ \\
\hline HH Labor Income (Parent) & 1,084 & $\$ 26,646$ & $\$ 16,671$ & 0 & $\$ 115,000$ \\
\hline $\begin{array}{l}\text { White Household Head } \\
\text { (Parent) }\end{array}$ & 1,084 & 0.858 & 0.349 & 0 & 1 \\
\hline $\begin{array}{l}\text { Black Household Head } \\
\text { (Parent) }\end{array}$ & 1,084 & 0.098 & 0.297 & 0 & 1 \\
\hline American Indian Household & & & & & \\
\hline Head (Parent) & 1,084 & 0.004 & 0.060 & 0 & 1 \\
\hline $\begin{array}{l}\text { Asian Household Head } \\
\text { (Parent) }\end{array}$ & 1,084 & 0.004 & 0.064 & 0 & 1 \\
\hline $\begin{array}{l}\text { Hispanic Household Head } \\
\text { (Parent) }\end{array}$ & 1,084 & 0.030 & 0.169 & 0 & 1 \\
\hline $\begin{array}{l}\text { Married Household Head } \\
\text { (Parent) }\end{array}$ & 1,084 & 0.902 & 0.297 & 0 & 1 \\
\hline Never Married Household & & & & & \\
\hline Head (Parent) & 1,084 & 0.039 & 0.193 & 0 & 1 \\
\hline $\begin{array}{l}\text { Widowed Household Head } \\
\text { (Parent) }\end{array}$ & 1,084 & 0.005 & 0.074 & 0 & 1 \\
\hline $\begin{array}{l}\text { Divorce Household Head } \\
\text { (Parent) }\end{array}$ & 1,084 & 0.040 & 0.196 & 0 & 1 \\
\hline $\begin{array}{l}\text { Separated Household Head } \\
\text { (Parent) }\end{array}$ & 1,084 & 0.013 & 0.115 & 0 & 1 \\
\hline High School Graduate & & & & & \\
\hline Household Head (Parent) & 1,084 & 0.795 & 0.404 & 0 & 1 \\
\hline College Graduate & & & & & \\
\hline Household Head (Parent) & 1,084 & 0.195 & 0.397 & 0 & 1 \\
\hline $\begin{array}{l}\text { High School Graduate Wife } \\
\text { (Parent) }\end{array}$ & 971 & 0.914 & 0.281 & 0 & 1 \\
\hline
\end{tabular}


College Graduate Wife

(Parent)

971

0.340

0.474

0

1

Household Head Works

Full time (Parent)

1,084

0.952

0.215

0

1

Wife Works Full Time

(Parent)

971

0.330

0.470

0

1

Union Household Head

(Parent)

1,084

0.214

0.410

1

Union Wife (Parent)

971

0.078

0.268

0

0.499

0

1

Blue Collar Father (Parent)

1,084

0.460

0

1

White Collar Father

(Parent)

$1,084 \quad 0.524$

0.500

0

1.986

0

1

Child Grades Completed

1,084

14.68

Child Works Full time

1,084

1

0

1

Child Health (1-5, 1 is

excellent)

1,084

3.87

.836

1

5

Child Rural Upbringing

$\begin{array}{ll}1,084 & 0.086\end{array}$

0.281

0

1

Child Urban Upbringing

Child Suburban Upbringing

1,084

0.250

0.433

0

1

$1,084 \quad 0.436$

0.496

0

1

Child Other Upbringing

1,084

0.029

0.169

0

1

Child Labor Income

1,084

$\$ 46,311$

$\$ 29,391$

0

$\$ 225,000$

Child Family Income

1,084

$\$ 72,586$

$\$ 60,984$

$\$ 3,600$

$\$ 1,553,500$

Child Union Status

1,084

0.131

0.338

0

1

Child Age

1,084

31.06

3.38

25

37

Note: "Child" statistics represent the characteristics of individuals who were under age 12 in 1985 , had at least one parent work full time in 1985, and worked full time in 2011. "Parent" statistics represent characteristics of their parents. 


\section{Appendix B: Issues in Linking Commuting Zone Data from "Intergenerational Mobility Statistics and Selected Covariates by County" and Unionization Data from Unionstats.org}

There are problems in linking the geographic area incomes from the tax data and the geographic union densities from the Unionstats.org data. The average parent and offspring income data relate to counties and commuting zones $(\mathrm{CZ})$, which are themselves collections of counties. The union data are available on the MSA level, which are also collections of counties (except in New England, as described below). Our geographic analysis takes place on the $\mathrm{CZ}$ level. The primary advantage of CZs over MSAs is that the CZ file of Chetty et al. comes with state IDs, which allows us to use standard errors clustered at the state level to control for geographic and state-specific correlations. Both CZs and MSAs often cross state boundaries (the Washington, DC MSA and CZ cover the District of Columbia, Maryland, and Virginia), but the MSAs do not have state IDs and thus we cannot use state clustered standard errors. We assign to each county the union density of the MSA to which it belongs and then combine these estimates into CZs, dropping counties that are not part of MSAs since we do not have union data for them. But we do not believe this is a serious problem: the correlation between the mobility estimates of our limited CZs and the whole CZs is .94.

Additionally, we reconstruct the covariates so that they only include counties for which we have union data.

Another problem in forming our mobility/unionization area data set is that the unionization data for the New England states differs from that for the rest of the country. Instead of MSAs (which are collections of entire counties), they are New England City and Town Areas (NECTAs), which are collections of towns. Thus, counties can belong to multiple MSAs. Fairfield County, CT, for example, belongs to the Danbury, Stamford-Norwalk, and Bridgeport NECTAs. To deal with this problem, we take the average of the union densities of the NECTAs to which each county belongs from UnionStats.com, weighted by the portion of their 2000 population that lived in each NECTA. For Fairfield County, CT, for example, we average the union densities of 
Danbury (17.5\%), Stamford-Norwalk (10.7\%), and Bridgeport (15.9\%) weighted by each of their 2000 populations (183,303, 353,556, and 345,708 respectively). This produces an estimated union density of $14.15 \%$ for Fairfield County. We then merge these county-level union estimates with county-level income estimates and other covariates, and collapse them into $\mathrm{CZs}$ based on counties.

Finally, because we do not have union data outside of MSAs, our analysis does not apply to rural areas. The total population of our CZs in 2000 was 207 million compared to a US population in 2000 of 282 million). While it may make sense to treat rural areas differently than MSAs, there is no way to obtain unionization rates for rural areas to see whether our results do/not hold for them. 


\section{Appendix C: Summary Statistics from the Regional Data from}

Federal Income Tax Data

\begin{tabular}{|c|c|c|c|c|c|}
\hline VARIABLES & $\mathrm{N}$ & Mean & SD & Min & Max \\
\hline Union density, 1986 & 203 & 0.156 & 0.078 & 0.025 & 0.407 \\
\hline Primary Sector & 203 & 0.015 & 0.019 & 0.001 & 0.123 \\
\hline Secondary Sector & 203 & 0.214 & 0.063 & 0.084 & 0.462 \\
\hline Tertiary Sector & 203 & 0.595 & 0.451 & 0.449 & 0.720 \\
\hline Quartenary Sector & 203 & 0.077 & 0.027 & 0.027 & 0.200 \\
\hline Quinary Sector & 203 & 0.051 & 0.026 & 0.022 & 0.194 \\
\hline Other Sector & 214 & 0.049 & 0.005 & 0.038 & 0.068 \\
\hline Percent Black & 203 & 0.122 & 0.107 & 0.003 & 0.468 \\
\hline Percent Hispanic & 203 & 0.085 & 0.125 & 0.005 & 0.869 \\
\hline Percent Asian & 203 & 0.024 & 0.039 & 0.002 & 0.453 \\
\hline Percent White & 203 & 0.746 & 0.157 & 0.119 & 0.977 \\
\hline Percent Other Race & 203 & 0.023 & 0.023 & 0.004 & 0.258 \\
\hline Gini Coefficient & 203 & 0.445 & 0.066 & 0.248 & 0.630 \\
\hline Children per Family & 203 & 2.054 & 0.112 & 1.826 & 2.600 \\
\hline Average Parents Income & 203 & $\$ 84,487$ & $\$ 18,219$ & $\$ 41,711$ & $\$ 149,210$ \\
\hline Average Child Income & 203 & $\$ 46,458$ & $\$ 5,997$ & $\$ 32,100$ & $\$ 64,121$ \\
\hline \multicolumn{6}{|l|}{ Percent with Commute $<15$} \\
\hline Minutes & 203 & 0.314 & 0.071 & 0.151 & 0.508 \\
\hline Single Mother Families & 203 & 0.227 & 0.039 & 0.094 & 0.355 \\
\hline Social Capital & 201 & -.252 & 1.006 & -2.723 & 2.397 \\
\hline Dropout Rate & 163 & 0.048 & 0.021 & 0.011 & 0.155 \\
\hline Median House Value & 203 & $\$ 114,108$ & $\$ 48,573$ & $\$ 52,622$ & $\$ 407,865$ \\
\hline Child Poverty Rate & 203 & 15.52 & 5.066 & 5.300 & 41.244 \\
\hline EITC Exposure & 203 & 1.166 & 3.439 & 0 & 21.33 \\
\hline Tax Progressivity & 203 & .988 & 1.849 & 0 & 7.220 \\
\hline
\end{tabular}




\section{Appendix D: Union Density and Intergenerational Mobility for Children Whose Parents were at the $25^{\text {th }}$ Percentile of the National Income Distribution}

Chetty et al. (2014) emphasize a different concept of intergenerational mobility focusing on individual's rankings in the national income distribution. The preferred measure in their paper, which they call "absolute upward mobility (AM)," is the expected rank of the 2011-2012 income of a child whose parents' 1996-2000 incomes are at the 25th percentile of their national income distribution. They find that there is a substantial variation in the AM across the US.

As a robustness check, we also utilize the AM as an additional measure for intergenerational mobility. Appendix Table E displays the results from the regressions of $\mathrm{AM}$ on union density and other characteristics of CZs. Column 1 shows a strong correlation between AM and union density by CZs. The coefficient implies that a ten percentage-point increase in 1986 union density is associated with a 1.3 percentile increase in the expected income ranking of adult offspring who were born in a household at the $25^{\text {th }}$ percentile income distribution, regardless of the union status of parents. Thus, the coefficient may also be picking up some of the spillover effect of unionization within the region. Although most union workers will be ranked higher than the $25^{\text {th }}$ percentile, unions generally support raising minimum wages and other policies that increase mobility. Thus, children from disadvantageous family backgrounds may be able to move up the income ladder more in terms of ranking if they grew up in areas with higher union density than in areas with lower union density.

To assess the relative strength of this correlation between the AM and the union density, we compare it to the correlation between AM and the five factors that Chetty et al. found to have the strongest relationship with AM: the percent of children with single mothers as parents, the income-adjusted dropout rate, the level of social capital, the percent of workers with commutes under 15 minutes (a measure of segregation), and inequality as 
measured by the Gini coefficient. ${ }^{19}$ We normalize all covariates and the AM for better comparison. Columns 2 through 7 show that the correlation between mobility and union density is about the same magnitude as the correlation between mobility and dropout rates, social capital, or segregation. Columns 8 and 9 report the coefficients from the multilevel regression of the AM on union density and the other covariates. In column 8, even after controlling for all five factors, the union density still shows a significantly positive association with the AM. In column 9, we control for several other covariates race, industry, median housing value, the number of children per family, tax progressivity, the existence of a state EITC, and the number of children below the poverty line - in additional to the five factors, and union density still remains significant.

\footnotetext{
${ }^{19}$ Chetty et al.(2014) find a Gini coefficient of just the bottom 99 percent of households has a stronger negative association with mobility than an overall Gini does. We use the overall Gini, however, because they do not provide a bottom 99 percent Gini by county and it comes from their federal tax data so public data could not be used.
} 
Appendix E: The Correlation between “Absolute Upward Mobility (AM)” and Union Density within CZs

\begin{tabular}{|c|c|c|c|c|c|c|c|c|c|}
\hline VARIABLES & $\begin{array}{l}\mathrm{AM} \\
(1)\end{array}$ & $\begin{array}{c}\text { AM_norm } \\
\text { (2) }\end{array}$ & $\begin{array}{c}\text { AM_norm } \\
\text { (3) }\end{array}$ & $\begin{array}{c}\text { AM_norm } \\
\text { (4) }\end{array}$ & $\begin{array}{c}\text { AM_norm } \\
(5)\end{array}$ & $\begin{array}{c}\text { AM_norm } \\
\text { (6) }\end{array}$ & $\begin{array}{c}\text { AM_norm } \\
\text { (7) }\end{array}$ & $\begin{array}{c}\text { AM_norm } \\
\text { (8) }\end{array}$ & $\begin{array}{c}\text { AM_norm } \\
(9)\end{array}$ \\
\hline 1986 Union & $12.90 * * *$ & & & & & & & & \\
\hline Density & (4.579) & & & & & & & & \\
\hline 1986 Union & & $0.333 * * *$ & & & & & & $0.386^{* * *}$ & $0.259 * * *$ \\
\hline Density_norm & & $(0.118)$ & & & & & & $(0.131)$ & $(0.097)$ \\
\hline Dropout & & & -0.274 & & & & & -0.050 & $-0.130 * *$ \\
\hline Rate_norm & & & $(0.110)$ & & & & & $(0.088)$ & $(0.52)$ \\
\hline Social & & & & $0.270 * *$ & & & & 0.444 & -0.030 \\
\hline Capital_norm & & & & $(0.132)$ & & & & $(0.084)$ & $(0.072)$ \\
\hline Single & & & & & $-0.625^{* * *}$ & & & $-0.576 * * *$ & -0.166 \\
\hline Mothers_norm & & & & & $(0.061)$ & & & $(0.078)$ & $(0.115)$ \\
\hline Commute time & & & & & & $0.255^{* * *}$ & & $0.214^{* *}$ & $0.196^{* *}$ \\
\hline$<15$ min_norm & & & & & & $(0.090)$ & & $(0.090)$ & $(0.070)$ \\
\hline Gini Coefficient & & & & & & & $-0.367 * * *$ & $0.123^{* *}$ & -0.119 \\
\hline Overall_norm & & & & & & & $(0.112)$ & $(0.113)$ & $(0.078)$ \\
\hline Other covariates & & & & & & & & & YES \\
\hline State clustered SE & YES & YES & YES & YES & YES & YES & YES & YES & YES \\
\hline Observations & 203 & 203 & 163 & 201 & 214 & 203 & 203 & 161 & 161 \\
\hline R-squared & 0.111 & 0.111 & 0.070 & 0.073 & 0.392 & 0.065 & 0.135 & 0.54 & 0.783 \\
\hline
\end{tabular}

Note: Clustered standard errors in parentheses. ${ }^{* * *} \mathrm{p}<0.01,{ }^{* *} \mathrm{p}<0.05,{ }^{*} \mathrm{p}<0.1$. All variables are normalized, except for the first column. Other covariates include race, industry, median housing value, the number of children per family, tax progressivity, the existence of a state EITC, and the fraction of children below the poverty line within MSA. 